\title{
Pre-Post-Apocalyptic Culture: The Future(s) of the Humanities
}

\author{
She walks through her sunken dream \\ To the seat with the clearest view \\ And she's hooked to the silver screen \\ But the film is a saddening bore! \\ For she's lived it ten times or more \\ She could spit in the eyes of fools \\ As they ask her to focus on \\ Sailor's fighting in the dance hall \\ Oh man! Look at those cavemen go \\ It's the freakiest show, \\ Take a look at the law-man \\ Beating up the wrong guy \\ Oh man! Wonder if he'll ever know \\ He's in the best-selling show, \\ Is there life on Mars?
}

These words are from David Bowie's popular song (Is there) Life on Mars?, which was released in 1971. I want to suggest that the reason why the song has, and continues, to be so popular is because it speaks strongly to our cultural imaginations, that is, it speaks to where we are going as societies, cultures, and as a species (or not), and it projects, and therefore anticipates, a future time and place that, like all good sci-fi, captures our imaginations, and projects our hopes, fears, horrors, dreams, and our wonder onto something somewhere else, if not better. Apart from being a cultural phenomenon in and of itself that has consequently, to some extent, had a huge influence on the way people feel about space, time, and the future, Bowie's song, while making reference to great musicians, filmmakers, and philosophers, is also a political commentary on our times. The song therefore serves as a good sci-fi trope, to which I will keep referring throughout this paper, for thinking about the "futures" of studying culture in the political climate of today and tomorrow.

Let me start by giving you Bowie's description of the meaning of his song: "A sensitive young girl's reaction to the media [or to the film she is watching on the silver screen] [...] she finds herself disappointed with reality [...] that although she's living in the doldrums of reality, she's being told there's a far greater life somewhere, and she's bitterly disappointed that she doesn't have access to it" (Pegg 2011, 144). The question "Is there life on Mars?" then could be interpreted as a plea, a call, to that something "other" as Jacques Derrida would say; to a 
future, to another world that may perhaps come or save us, as the girl in the song seems to crave, from our "caveman"-like behaviors that we paradoxically exhibit in our modern times. We could argue the question of the song's title is a call to and for a new Enlightenment, not one solely determined by privileging reason and autonomy or individual monadism (in the Kantian sense), but rather one that also includes a more contextual connection between people, and the environments (both local and global) in which we live.

However, while Bowie's song has shaped the public imagination about space and the future, I would also argue that he does not necessarily present a utopic vision. This is because the question: "Is there life on Mars?" is also dystopic precisely because the question remains only a question. It is therefore perhaps a cynical political and cultural commentary on the times (the 1970s), but one just as relevant and pertinent today. In other words, the question becomes a commentary on the way we culturally represent ourselves to each other. For example, the girl watching a film about "sailor's fighting" and a "law-man beating up the wrong guy" that she has experienced in reality "ten times or more", suggests a repetitive and circular representation of ourselves, one that endorses and perpetuates the simplistic "caveman"-like behavior in the media and on the silver screens, of our politicians, lawyers, and war-machines: "Oh man! Look at those cavemen go." At the very end of the song there is a drumbeat that is an intertextual musical reference to Stanley Kubrick's film 2001: A Space Odyssey (which was released in 1968, 3 years before Bowie's song). The drumbeat in the movie's theme song, referenced by Bowie, is taken from German composer Richard Strauss's composition, Also sprach Zarathustra (1896). One of the scenes in the movie accompanying Strauss's music is the ape (or early "caveman") throwing a bone into the sky. The bone, a symbol of the tools and weapons humans learn to use, brings us right back - and thus repeats the circularity of human behavior - to the line in Bowie's song: "Oh man! Look at those cavemen go." But the title of Strauss's music, is in turn, as we know, a reference to Friedrich Nietzsche's famous book, Thus Spoke Zarathustra (1883-1891), in which Nietzsche opposes Immanuel Kant's form of Enlightenment (or ascetic ideal). Rather, as Paul Patton argues, Nietzsche believes in the "possibility of a different type of human being, the 'overman' represented by the coming of a child without ressentiment at the natural conditions of life, including death, and with no need of a belief in super-sensible worlds," that is, belief in worlds we cannot experience with our senses and are therefore transcendent (including alien worlds) (Patton 2012, 139, 142-143). The child in Bowie's song that references Strauss's Also sprach Zarathustra and in turn 2001: A Space Odyssey (1968) could be reminiscent of the coming of the child that represents Nietzsche's overman. And while Space Odyssey also projected a "future human," perhaps an Nietzschean "overman" in space, on the ground, on earth, in 1968, 
we saw various anti-authoritarian revolutions of varying intensity throughout Europe: in Poland, Prague, Germany, and arguably most famously in Paris with the student riots that brought the nation to a standstill in just over a couple of weeks. Much of the revolts at this time, as Angela Merkel put it, was a response to the political repressive socialism of the day on the one hand, and the freemarket economy that in turn was blamed for appalling conditions for workers and increased fees for students on the other (Dülffer 2008).

In summing up the " 68 movement on its fortieth anniversary in 2008, Daniel Cohn-Bendit claimed that "1968 was a European movement," one that "gave rise to a new form of society all over Europe. Today we are on the path to a common identity" (Cohn-Bendit 2008). Compare that to what is happening in Europe now, and reflect on the fact that only nine years after Cohn-Bendit's claim, on 23 June, 2016, the UK voted to leave the EU (what has been termed “Brexit”). In the immediate aftermath of the vote to leave the EU, there were threats from Ireland and Scotland for a new referendum to leave the UK, and talk of Nexit (the "next" country touted to leave was the Netherlands). If there was a common identity or a potential for one, it was shattered on 23 June, 2016. The line in Bowie's song in which he sings "Rule Britannia is out of bounds" is uncannily prophetic, evidenced by a display of sovereignty when Boris Johnson made clear in his speech on the morning of the outcome of the vote that "we can now take back democratic [meaning sovereign] control ... we can control our own borders" (Johnson 2016). And as Philip Stephens in his column in the UK Financial Times on 23 June argued: "The 2008 financial crash, austerity and the grossly uneven distribution of the rewards of globalisation have all taken a toll” (Stephens 2016). This is indeed a far cry from a united EU on a path to a "common identity," as Stephens goes on: "Not so long ago British politicians of almost all shades were proud of Europe's role as a catalyst for the spread of freedom and democracy beyond its borders. Governments of right and left championed the EU accession of formerly communist states" (Stephens 2016). But now, and quoting this time politician and Brexit supporter Michael Gove, "people in this country have had enough of experts" (Gove 2016). Indeed, those experts are not just "organisations" initially suggested by Gove, but one could argue they also include academics and academic institutions. I'll come back to this disillusionment with academic experts shortly, but for the moment while it is possible to see the Brexit revolt as a repetition of political uprisings of the 1960s, as Karl Marx argues such repetitions are often in form only because history repeats itself "once as tragedy and again as farce” (Marx 2013 [1852], 9), or as Bowie sings: It's an old story, seen "ten times or more.”

This discussion of Brexit is an example, a case study, or a way to think about the statement, "the futures of studying culture," because the vote to Leave was much more than just about economics, politics, fear of terrorism, and dislike of 
immigration. It is, I would argue, also about culture and 'identity.' Indeed for some, such as David Morris, it represents the new culture wars between classes and between the left and right: "The most overwhelming Leave constituencies are a social milieu that is remote, both literally and figuratively, from higher education [...] Class, education and geography dominate above all else, far more so than the policy debates about the economy and immigration" (Morris 2016). Moreover, no longer wanting a cosmopolitan identity, Britons have been lamenting a longpassed idea of "Britishness" (and thus culture), which they believe immigration has diluted (McQuillan 2016a). My aim here is not to side or comment on whether or not Britain was right or wrong to decide to leave the EU. Rather what is more interesting is that Brexit not only exposed the fault lines in class relations, but that in the lead-up to and fall-out from the vote, while there were many academics commenting about the economic and political implications of Brexit, there were very few academic voices linking the debate to ethics, responsibility, and social justice.

Jacques Derrida would definitely have had something to say, and in fact, still does, when we consider how and why his work has ongoing relevance. For instance, writing on the mass demonstration in Paris in 1996 over the issue of refugees and immigration, in his article "On Cosmopolitanism" (2001), which is relevant to the Brexit issue today, Derrida rigorously unpacks the issues by focusing on the word "cosmopolitanism.” Derrida argues that "[s]ince the Revolution," France has portrayed its cosmopolitan identity by "being more open to political refugees in contradistinction to other European countries" (Derrida 2001, 10). And yet, despite this, Derrida locates a double bind or contradictory imperative within the concept of cosmopolitanism. As summarized by Simon Critchley and Richard Kearney in the preface to Derrida's article:

[O]n the one hand, there is an unconditional hospitality which should offer the right of refuge to all immigrants and newcomers. But on the other hand, hospitality has to be conditional: there has to be some limitation on rights of residence. All the political difficulty of immigration consists in negotiating between these two imperatives.

(Derrida 2001, x)

I would argue that any negotiation of this nature involves ethics because it has to account for the needs of both hosts and refugees. Of course Derrida has a lot more to say about this negotiation and the nature of hospitality, and while Derrida wrote "On Cosmopolitanism" in 1997, twenty years later we could say that the Brexit vote to Leave was perhaps a failure by our politicians to take on this negotiation and a further failure of both academics and politicians to even communicate the issues involved to the general population. Still I can't help wondering what Derrida would have to say about this situation. I recall a conversation 
Derrida and I were having about 1968, in which he was telling me that intellectuals (the professors) en masse were supporting, and were often found on the front line with, the students and workers. Foucault was one of them, and Derrida harbored in his home some of the student rioters wanted by authorities. And while the situation is different today, and while there are many academic commentators on Brexit, the questions remain: where are the professors, the intellectuals, the academics today, not just as commentators on an event like Brexit, but shapers of the future of culture and politics and our responsibilities and ethics towards others, to all communities and classes in our societies? Or, to put the question another way: What should be the role of higher education in a situation like Brexit? To some British academic commentators there is an argument that the lack of an active role in Brexit by higher education institutions has created a legitimation crisis. Max Weber and Jürgen Habermas broadly define a legitimation crisis as a situation in which the citizens of a political regime lose belief in the system, such as, public institutions (Weber 2012, 382; Habermas 1987, 140; see also Habermas 1975). Now some British academic commentators have been arguing that a legitimation crisis was played out in and through Brexit, with the vote to Leave as much about an economic as it was an anti-intellectual or a higher education legitimation crisis. The crisis can be summed up by Martin McQuillan when he argues:

The widening of the graduate population and the expansion of immigration to the United Kingdom are perhaps the two most significant factors that have changed the cultural composition of Britain in the last two decades. The EU vote is a direct challenge to the latter; it also feels like a warning shot to the former. As the so-called "post-truth" politics of the campaign demonstrated, it is not an exaggeration to say that the referendum was an antiintellectual experience and that the outcome is a rejection of the values espoused by those in universities who argued for Remain.

(McQuillan 2016b)

Indeed, 103 universities in the UK wrote an open letter to the British voters appealing to them to vote Remain. But admirable as this was, and while it was absolutely needed, in some ways the letter missed its mark and failed to take account of this culture war and this anti-intellectualism that McQuillan comments on. Beginning the open letter with this line, "we are gravely concerned about the impact of a UK exit from the EU on our universities and students" (Independent 2016), we can perhaps see why it missed its mark. The letter did not address at all what universities could do for those working classes who do not share the same values, who are simply struggling to survive, and often have no chance or opportunity of ever getting to university. After all, to use Bowie's interpretation of his song: "the girl is being told there's a far greater life somewhere, and she's bitterly disappointed that she doesn't have access to it” (Pegg 2011, 144). 
Of course in this climate of legitimation crisis the university and research communities are easy targets. Because while universities argued that leaving the EU would be a mistake, could not be supported by any reasonable evidence, and would be bad for national institutions such as universities, as David Morris argues, "[t]he sceptical listener only hears self-interest and a wish to preserve the status quo above all else," and they hear this precisely because "[t]he highly educated and their educators have done relatively well in Britain since the recession and austerity, even with the diversity of experience within these groups" (Morris 2016). In other words, within some western societies, large portions of the population, not just Britain, are tilting in terms of their cultural values to the extreme right, and what this means, as Philip Stephens puts it, is that increasingly "[f]ear counts above reason, anger above evidence, lies and prejudice claim equal status with facts, and political popularism wins the day, and this is a consequence of trust in democratic and educational institutions being at a very low point in the history of Western democracy" (Stephens 2016). But when academics start to associate political popularism with the ignorance of the masses, this ironically just widens the cultural and class divide and further perpetuates mistrust in academic institutions. One could just as easily argue that, like the working class response, the educated position of being for "Remain" is equally ideological and/or a knee-jerk reaction because, as I mentioned earlier, it is perhaps based on thinking of the working class as uneducated bigots, and thus not really paying attention to the desperation coming from austerity measures and the failure of neoliberalism to distribute wealth fairly. But perhaps this situation may have been averted if the role of higher education, and here I particularly include the humanities and cultural studies, had contributed (say through more effective public discourse and through extensive and consistent influence on the secondary school system) to developing a citizenry that would be capable of making informed decisions: that is, decisions based on being able to critically choose among various options articulated in one form or another between the left and right and necessary for understanding not only the complexity but the ethical implications of a given situation or event like Brexit. Therefore, perhaps it is ethical education and decision-making that will enable us to go beyond the ideologies of both left and right so that we can negotiate and make informed decisions with the others' interests in mind. That is, ethical education enables us to focus on the interests and needs of the other, no matter how different they may be to "us."

Meanwhile, if Brexit has revealed a legitimation crisis in Higher Education, then we can conclude that academics are seen as part of an elite, as experts in control (economically and intellectually) who have let the people down. In this Brexit climate that will effect Europe, as well as in the larger world context of 
potential ecological and hence political crisis with increasing refugees and immigration born out of war, fundamentalism and climate change (Syrian refugees are partly a result of climate forces as well), with the forthcoming struggle for raw materials, such as food and water, and with the closing or policing of borders, the explosions of social divisions and exclusions, that is, increased tribalism and forms of apartheid (Žižek 2016), it is no wonder that a discourse of postapocalyptic culture is on everyone's lips, and why Slavoj Žižek's (2016) claim that we are "living in end times" and approaching an apocalyptic state taps into the current Zeitgeist. In fact, as Claire Colebrook puts it, this explains why "Fredric Jameson suggested that it was easier to imagine the end of the world than the end of capitalism" (Colebrook 2016, 21; see Jameson 2003, 76). In fact, this could be called a pre-post-apocalyptic culture precisely because it is, and it will be climate change and fundamentalism, coupled with the rise of the Internet and the supposed democratization of knowledge, that differentiates us now from 1968 and other political upheavals of the past.

Given all of this, given the talk of living on the verge, or in a pre-post-apocalyptic culture, given the alleged demise in trust in academic institutions, there seems to be an increasing dominant way of thinking about the future of studying culture and the humanities, and that is, that the humanities will either slide into non-existence, in other words, there is no future at all, because, with the mistrust in 'experts' such as academics, universities and particularly the study of the humanities, including culture, will be seen as increasingly indulgent by the general populace, or we will nonetheless muddle along catering only to a small elite cut off from the mainstream and increasingly less relevant and a tiny voice that makes no difference among the dominant political issues of the day. Unless academics have given up entirely, this view looks bleak.

But why care? Should we care? When Žižek and other philosophers tell us we are living in the "end times," like good cultural theoreticians, the question we need to be raising here, as Claire Colebrook argues, is "whose 'end times' and whose 'world' [is] deemed to be ending?" (Colebrook 2016, 21). Put more concretely: The "end of the world" that is being pre-emptively mourned in postapocalyptic culture is a highly specific world of hyper-consuming, personalized, neoliberal, and narrowly post-human "man." It is only possible to say that "we" are easily imagining the end of the world when what is presented as "the end" in films, pop-songs, and philosophy "is the end of Western affluence and white privilege" (Colebrook 2016, 22). We could put the question to higher education institutions as well. It could well be argued and indeed has been that implicit in statements like "the futures of studying culture" or the "value of the humanities" (and you could replace humanities with universities here), is a mournful narcissism of our own values, beliefs, ideologies, and privileged positions. 
Having said this, whether or not we are on the verge of a post-apocalyptic culture is actually not the issue. If there is some kind of apocalypse (whether it is nuclear, viral, terrorist, etc.), when and if it happens, everything, let alone the question of the future of studying culture will be redundant. As Derrida argues, the absolute future is unpredictable, incalculable, absolutely unknowable, and therefore unpreventable, and this is what Derrida calls the "future to come" (Derrida 1994, xix). However, there is also another future, what Derrida calls the "future-present" (Derrida 1976, 67). This is a near future, one that can be calculated and anticipated based on the present and the past, and through reason and imagination this future can be shaped (shaped enough to perhaps prevent our own man-made apocalypse). Therefore, this for me is the future of which we can take hold. A future in which we can assert the value of the humanities, or the futures of studying culture, as I do, as a more positive and hopeful attempt to step out of this narcissism and make ourselves relevant to the people that need us. After all, helping politicians, journalists, and the general public understand and solve the social and ethical issues of our age is the university's, and especially the humanities', most pressing mission. For Morris, the "challenge is to make the complexities and caveats of research resonate with the everyday experience of citizens" (Morris 2016). The alternative is to waste away in crumbling ivory towers, relics, or ruins of an age past.

The study of culture, and the humanities more broadly, offers the perfect position to help others understand our social and cultural problems and provide answers to them; with the theoretical and empirical tools in our toolbox we have the ability to respond to the most important issues of our times with flexibility and with speed. The study of culture, and the humanities, provides not only knowledge and understandings of human behavior, society, and culture, but also what it means to be human. Moreover, the study of culture and the humanities knows how to tell a story about who we are and where we are going, much like Bowie's song; the humanities need to tell that story more strongly, and through that story start shaping the cultural, social, political, and ethical imagination in positive and socially just ways.

Furthermore, unlike the current break-up of the EU, what is needed now more than ever is that cultural studies and the humanities collaborate with the sciences (in research and in teaching), which will involve translating the ways in which various disciplines see the world, and use various theoretical and empirical frameworks to provide a new vision of the world, as well as new innovative implementations of those visions. Unlike the EU breakup, we need to come together in unity (not cynically for our own economic survivals as C.P. Snow (1959) writing in the 1950s analyzed the reason for the divide between the humanities and sciences); we need to come together around a bigger picture so 
that we can start shaping or at least influencing the way others will ethically see the future history of the world. The more relevance we have the more we will be in a position to grow the humanities (which has been on the decline since the 1970s) by influencing public perception. As Leonard Cassuto, professor of English and American Studies at Fordham University, stating the obvious, argues:

Administrators are looking outside the liberal arts because they feel financial pressure. The numbers show that liberal arts graduates actually do very well after graduation, but there is no denying that prospective college students - and their tuition-paying parents - do not believe that. The percentage of liberal arts majors is trending downward, and shrinking enrolments result in college teaching jobs that don't get replaced.

(Cassuto 2016)

If we care about studying culture and the humanities, if we care about the future of these things, then we should probably be asking ourselves the hard questions, if we aren't already. And I will pose some of those questions in a moment. I do believe there will be the humanities and the study of culture in the future, although it might not look like what it does today. So leaving aside the current discourse about the end of times (which we may very well be in), if we assume we are going to be around as a species, then the question is: When we think about the future/s of the humanities and the study of culture, how far into those future/s should our projections go? Should we think only of the next 10 years? In fact let's project into the far distant future, and let's assume that the answer to the question "Is there life on Mars?" in Bowie's song, is us: the human species.

When we teach culture and the humanities on Mars, what will it look like? On Mars the environment will obviously be different, and our responses to the "world" or planet around us will be different, therefore the students, teachers, and researchers will be different, and so too what we learn, teach, and research. In this Martian environment, which we might be able to populate thanks to our scientists and economists, what contribution will the humanities and cultural studies have made? What will the humanities and cultural studies equip us with to not only survive, but also live and become, in that environment? What do the humanities give us today to enable the potential for that possible future? How do we prepare our students today for the many possible futures that we can only imagine? How do we make ourselves relevant today to enable possible futures?

Here are a few ideas or answers to these questions (obviously they are not the only ones): The humanities and cultural studies are what help us to communicate our understanding of the world around us (whether it be on Mars or Earth). Or to put it another way, the humanities and cultural studies are the study of how we represent ourselves to each other (currently through philosophy or art; literature or film; sociology, languages, cultures, history, anthropology or social media, and so on). The humanities, then, give us the critical thinking and communication 
skills as well as the problem-solving tools in which to think laterally about, and respond flexibly and with speed to a fast-evolving world and the challenges of the times (now and in the future). Most importantly, the humanities teach us not only to communicate our understanding of the world around us to others, but enables us to transform, shape, or create the worlds we live in, as it provides us with the ability and the tools to describe visions for a better (ethical, moral, and socially just) future for all. It is through these critical thinking tools that we (not only students but also teachers and researchers) acquire the skills to learn and critically reflect. After all, if we as educators don't learn, and don't adapt by envisioning the future, then how can we teach and research? The future of the humanities in large part, then, comes down to what happens in the classroom and how we collaborate with each other as well as the sciences and industry here, now, today, and also the way we connect for, and convey or communicate to students and the general public, the relevance of the details and particularity of what is learnt in the classroom and in our research to the larger world in general.

Acknowledgement: This paper is based on my lecture at GCSC/GGK Anniversary Symposium “Futures of the Study of Culture”, July 7-8, 2016, Alte Gießerei (Justus Liebig University, Giessen, Germany). I thank Jens Kugele, Doris Bachmann-Medick, and Michael Basseler, and the GCSC board members, for inviting me to speak at this important symposium.

\section{References}

Cassuto, Leonard. “This Picture Tells a Story.” Inside Higher Ed (6 June 2016). <https://www. insidehighered.com/views/2016/06/06/responding-state-humanities-today-essay> [accessed: 28 February 2018].

Cohn-Bendit, Daniel. "Stop the Comparisons with 1968." Café Babel (23 January 2008). <http://www.cafebabel.co.uk/society/article/daniel-cohn-bendit-stop-thecomparisons-with-1968.html> [accessed: 28 February 2018].

Colebrook, Claire. "The Play of the World: The End, the Great Outdoors, the Outside, Alterity, and the Real." Derrida Today 9.1 (2016): 21-35.

Derrida, Jacques. Of Grammatology. Transl. Gayatri Spivak. Baltimore, MD: The Johns Hopkins University Press, 1976.

Derrida, Jacques. Specters of Marx. Transl. Peggy Kamuf. New York/London: Routledge, 1994. Derrida, Jacques. On Cosmopolitanism and Forgiveness. Transl. Mark Dooley and Michael Hughes. London/New York: Routledge, 2001.

Dülffer, Meike. “1968 - A European Movement?” eurotopics. European Press Review (March 2008). <http://archiv.eurotopics.net/en/home/presseschau/archiv/magazin/geschichteverteilerseite-neu/achtundsechzig-2008-03/debatte-1968-2008-03/> [accessed: 28 February 2018]. 
"EU Referendum: An Open Letter to UK Voters from Leaders of 103 British Universities." Independent (20 June 2016). <http://www.independent.co.uk/news/uk/politics/eureferendum-an-open-letter-to-uk-voters-from-leaders-of-96-british-universities-a7092511. html> [accessed: 28 February 2018].

Gove, Michael. “Interview with Faisal Islam.” Sky News (3 June 2016). <https://www.youtube. com/watch?v=GGgiGt)k7MA> [accessed: 29 November 2019].

Habermas, Jürgen. Legitimation Crisis. Transl. Thomas McCarthy. Boston: Beacon Press, 1975. Habermas, Jürgen. The Theory of Communicative Action. Vol. 2. Boston: Beacon Press, 1987. Jameson, Fredric. "Future City." New Left Review 21 (2003): 65-79.

Johnson, Boris. "Boris Johnson Hails Brexit Victory - Full Statement." The Telegraph (24 June 2016). <http://www.telegraph.co.uk/news/2016/06/24/boris-johnson-hails-brexitvictory---full-statement/> [accessed: 28 February 2018].

Marx, Karl. The Eighteenth Brumaire of Louis Napoleon. Transl. Daniel De Leon. Belmont, NC: Wiseblood Classics, 2013 [1852].

McQuillan, Martin. “Taking a Leave of our Senses in the EU Referendum.” Wonkhe Report (23 June 2016a). <http://wonkhe.com/blogs/comment-taking-a-leave-of-our-senses/> [accessed: 29 November 2019].

McQuillan, Martin. "The Morning After the Referendum the Night Before." Wonkhe Report (24 June 2016b). <http://wonkhe.com/blogs/comment-the-morning-after-the-referendumthe-night-before/> [accessed: 29 November 2019].

Morris, David. "What Next for Universities in Our Disunited Kingdom?” Wonkhe Report (23 June 2016). <http://wonkhe.com/blogs/comment-universities-dis-united-kingdom/> [accessed: 29 November 2019].

Patton, Paul. “McCarthy's Fire.” Styles of Extinction: Cormac McCarthy's The Road. Eds. Julian Murphet and Mark Steven. London/New York: Continuum, 2012. 131-144.

Pegg, Nicholas. The Complete David Bowie. London: Titan Books, 2011.

Snow, Charles P. The Two Cultures. Cambridge: Cambridge University Press, 1959.

Stephens, Phillip. “The Perils of a Populist Paean to Ignorance.” Financial Times (23 June 2016). <https://www.ft.com/content/bfb5f3d4-379d-11e6-a780-b48ed7b6126f> [accessed: 1 March 2018].

Weber, Max. The Theory of Social and Economic Organization. Eastford, CT: Martino Fine Books, 2012.

Žižek, Slavoj. Living in the End Times. London/New York: Verso, 2016. 